\section{To: (Receiving Organization)}

Distribution

5. Proj./Prog./Dept./Dlv.:

RPP Corrosion Probe

\section{Originator Remarks:}

This ATP will document the satisfactory operation of the corrosion probe destined for installation in tank 241-AN-104
3. From: (Originating Organization)

DST Maintenance \& Reliability Eng 6. Design Authority/Design Agent/Cog. Engr.:
EC Norman Resp.

4. Rolated EDT No.:

$\mathrm{N} / \mathrm{A}$

7. Purchase Order No.:

$N / A$

9. Equip./Component No.:

$\mathrm{N} / \mathrm{A}$

10. System/Bidg./Facility:

$\mathrm{N} / \mathrm{A}$

12. Major Asam. Dwg. No.:

$\mathrm{N} / \mathrm{A}$

13. Permit/Permit Application No.:

$\mathrm{N} / \mathrm{A}$

14. Required Responce Date: $N / A$

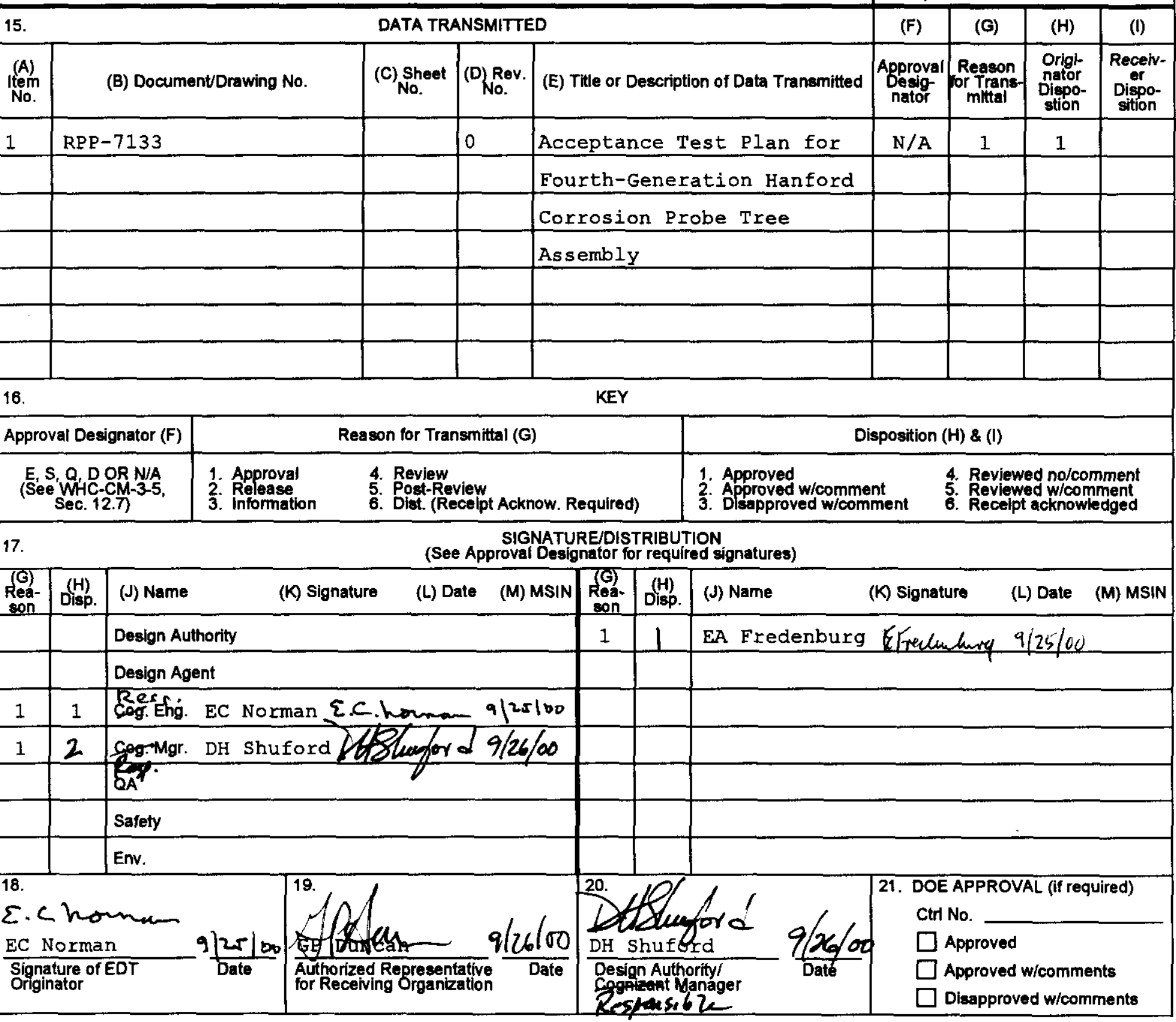




\section{DISTRIBUTION SHEET}

To

Distribution

Project Title/Work Order

RPP-7133, Acceptance Test Plan for Eourth-Generation Hanford

Corrosion Probe Tree Assembly

Name

EA Fredenburg

EC Norman

GP Duncan

JL Castleberry

GL Edgemon
From

DST Maintenance \& Reliability Eng

$\mid$

$\mathrm{R} 1-04$

$\mathrm{R} 1-04$

s6-15

$\mathrm{R} 1-56$

R3-83

$\mathrm{x}$

$x$

Page 1 of 1

Date September 25, 2000

EDT No. 630999

ECN No.

\begin{tabular}{c|c|c|c|c|} 
MSIN & $\begin{array}{c}\text { Text } \\
\text { With All } \\
\text { Attach. }\end{array}$ & Text Only & $\begin{array}{c}\text { Attach./ } \\
\text { Appendix } \\
\text { Only }\end{array}$ & $\begin{array}{c}\text { EDT/ECN } \\
\text { Only }\end{array}$ \\
\hline
\end{tabular}

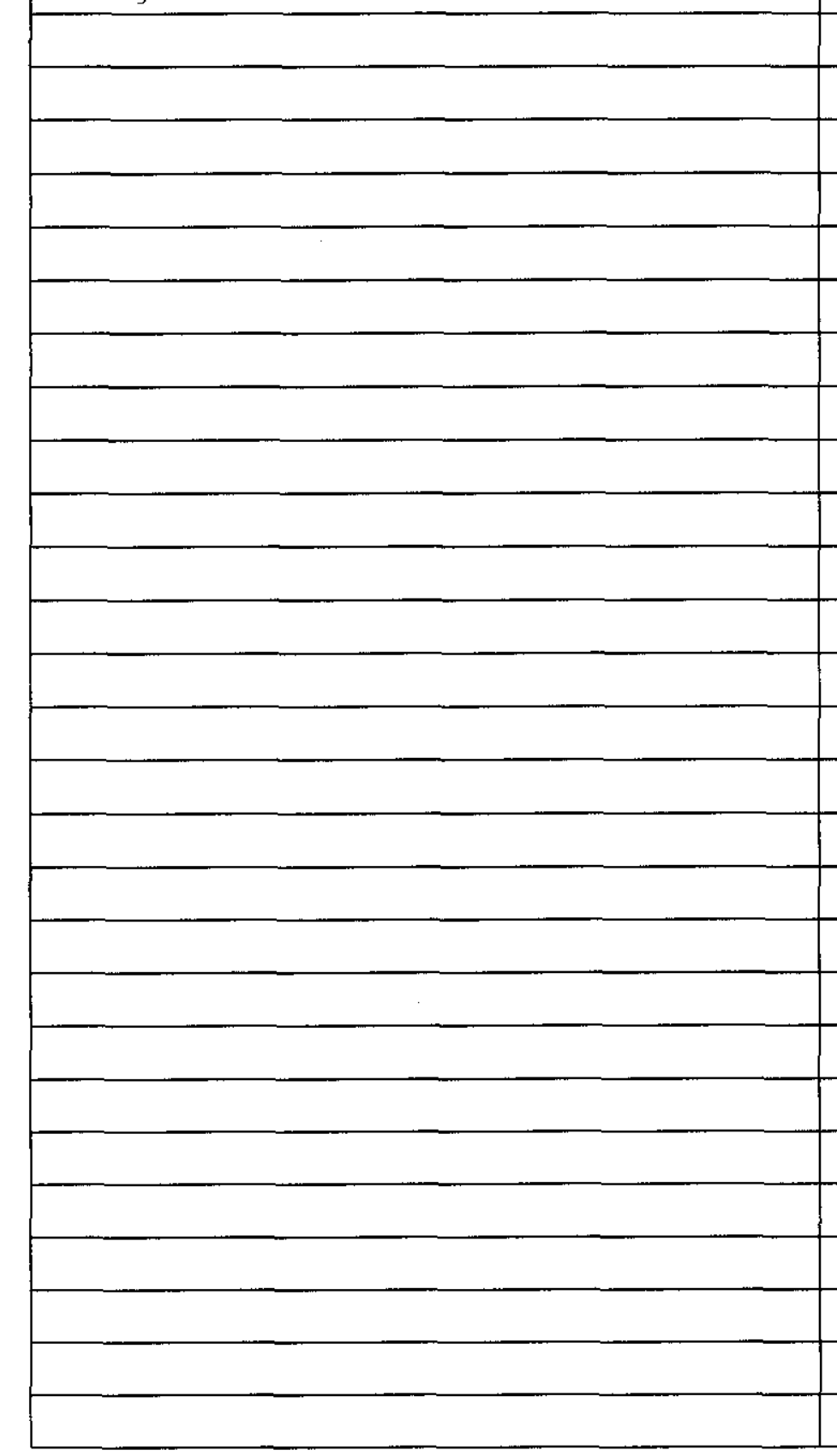

Ren

\begin{tabular}{|c|c|}
\hline & $x$ \\
\hline
\end{tabular}




\title{
Acceptance Test Plan for Fourth-Generation Hanford Corrosion Probe Tree Assembly
}

\author{
E. C. Norman \\ CH2M HILL Hanford Group, Inc. \\ Richland, WA 99352 \\ U.S. Department of Energy Contract DE-AC06-96RL13200

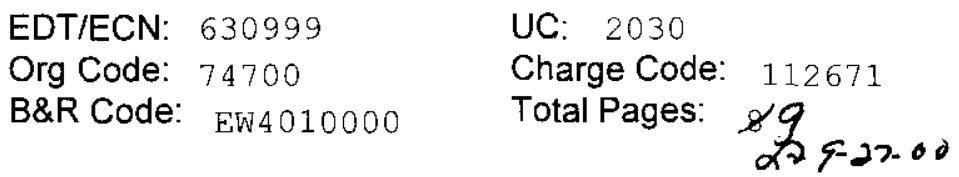

Key Words: corrosion monitoring/control, corrosion probe

Abstract: This Acceptance Test Plan (ATP) will document the satisfactory opearation of the corrosion probe destined for installation in tank 241-AN-104.

TRADEMARK DISCLAIMER. Reference herein to any specific commercial product, process, or service by trade name, trademark, manufacturer, or otherwise, does not necessarily constitute or imply its endorsement, recommendation, or favoring by the United States Government or any agency thereof or its contractors or subcontractors.

Printed in the United States of America. To obtain copies of this document, contact: Document Control Services, P.O. Box 950, Mailstop H6-08, Richland WA 99352, Phone (509) 372-2420; Fax (509) 376-4989.
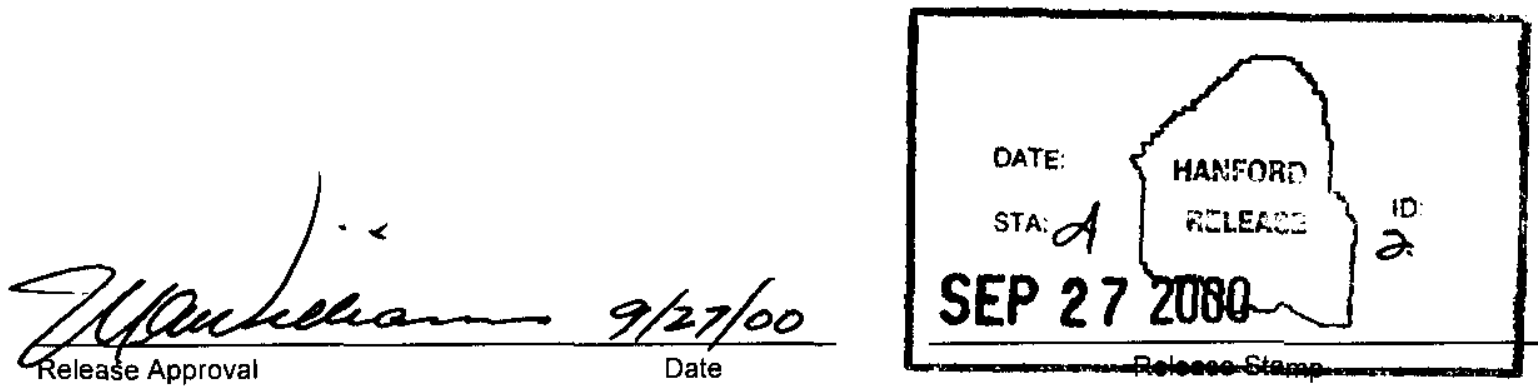

\section{Approved For Public Release}


RPP-7133, Rev. 0

\title{
ACCEPTANCE TEST PLAN FOR FOURTH GENERATION HANFORD CORROSION PROBE TREE ASSEMBLY
}

\author{
G. L. Edgemon \\ Hiline Engineering \& Fabrication, Inc. \\ 2105 Aviator Drive \\ Richland, Washington 99352
}


RPP-7133, Rev. 0

\subsection{PURPOSE}

This Acceptance Test Procedure (ATP) will document the satisfactory operation of the corrosion probe tree assembly. This ATP will be performed by the manufacturer prior to delivery to the site.

\subsection{TEST OBJECTIVES}

The objective of this procedure is to demonstrate and document the acceptance of the corrosion probe tree assembly. The test will consist of a pressure test to verify leak tightness of the probe tree body, a continuity test of the probe tree wiring, a test of the high level detector wiring, and a test of the operation of the Type $\mathrm{K}$ thermocouples.

\subsection{REFERENCES}

RPP-6380 "Design of Hanford Site's Fourth-Generation Multi-Function Corrosion Monitoring System "

\subsection{RESPONSIBILITIES}

\subsection{DST MAINTENANCE AND RELIABILITY ENGINEERING}

A member of the DST Maintenance and Reliability Engineering Organization shall be responsible for the coordination, scheduling, performance and documentation of this test procedure.

\subsection{TEST WITNESSES}

A member of the DST Maintenance and Reliability Engineering Organization shall perform the function of test witness. All corrosion probe tree assembly testing shall be witnessed, verified and approved with the Test Engineers signature

\subsection{DOCUMENTATION}

\subsection{TEST RECORD}

Any personnel involved in the performance of this test including the Test Engineer shall fill out a line in Section 8.0 RECORDS.

Test results shall be recorded by the Test Engineer. Unacceptable conditions or readings are to be referred to Section 9.0 EXCEPTIONS. A complete working copy of this procedure and all exception records shall be maintained as lifetime records in accordance with RPP-PRO222, Rev. 0, Quality Assurance Records Standards. 


\subsection{EXCEPTIONS}

Exceptions by step number, and other notes are to be recorded under Section 9.0. This section must be dispositioned (including the generation of any required ECNs) and signed off by the Test Engineer prior to final ATP acceptance. If no exceptions are encountered, this section shall be so noted and closed out with the signature of the Test Engineer. During the performance of this test errors in text may be encountered which require correction/adjustment to complete the test. The correction is to be noted in the ATP and listed as an exception in Section 9.0.

\subsection{TEST EXECUTION RECORD}

Approval of the ATP results shall be accepted by the Test Engineer as indicated by signature in Section 10.0.

\subsection{TEST EQUIPMENT}

- Calibrated Multimeter

- Air compressor

- Calibrated Pressure Gauge

\subsection{ACCEPTANCE TEST}

NOTE: Small leakage in the test apparatus is acceptable. Leakage from any component of the probe tree assembly is not acceptable (i.e. seal pins, fittings, welded joints, etc.). Test the final wired assembly with all fittings and seal pins in final configuration.

\subsection{LEAK TEST}

7.1.1 Record model, serial number, and calibration expiration date of pressure gauge below.

Instrument: SN:

Calibration Expiration Date:

7.1.2 Place an appropriate air fitting on one end of the probe body.

7.1.3 Connect air supply to fitting and fill probe body with air.

7.1.4 Pressurize probe body to between 20 psig minimum or 30 psig maximum. 
7.1.5 Hold pressure for 10 minutes or longer.

7.1.6 Apply "Snoop" solution to each fitting and welded joint.

7.1.7 Check for the formation of bubbles at fittings and joints.

7.1.8 If bubbles are detected at any of the joints, tighten the joint, if still leaking, disassemble joints that leaked and replace fitting, or seal pin. Rework any welds that are found to leak. Perform pressure testing steps again.

7.1.9 Test Engineer sign off that steps 7.1.1 through 7.1.8 are complete.

Test Engineer Date

\subsection{CONTINUITY TEST}

Using a standard multimeter, electrical continuity shall be verified between each of the 24 corrosion probe electrodes and it's respective pin in the connector at the top of the corrosion probe tree assembly. Continuity will also be checked between each of the two high level detector elements and its respective wire termination point in the enclosure at the top of the probe. To perform this continuity check make the necessary connections between the appropriate pin in the connector at top of the probe and the electrode being tested. The continuity check will be performed starting with channel 1, and ending with channel 8 . Each channel contains three electrodes leading to three unique pins in the connector at the top of the corrosion probe tree.

7.2.1 Record model, serial number, and calibration expiration date of multimeter below.

Instrument: SN:

Calibration Expiration Date:

7.2.2 Continuity check: Circle Yes or No in regard to whether continuity exists.

\begin{tabular}{ll} 
Pin\# & Continuity \\
\cline { 3 - 3 } a & Yes/No \\
$Z$ & Yes/No \\
Y & Yes/No \\
$X$ & Yes/No \\
W & Yes/No \\
V & Yes/No
\end{tabular}


Upper High

Level Detector

Element

Lower High

Level Detector

Element

$\begin{array}{ll}\text { U } & \text { Yes/No } \\ \text { T } & \text { Yes/No } \\ \text { S } & \text { Yes/No } \\ \text { R } & \text { Yes/No } \\ \text { P } & \text { Yes/No } \\ \text { N } & \text { Yes/No } \\ \text { M } & \text { Yes/No } \\ \text { L } & \text { Yes/No } \\ \text { K } & \text { Yes/No } \\ \text { J } & \text { Yes/No } \\ \text { H } & \text { Yes/No } \\ \text { G } & \text { Yes/No } \\ \text { F } & \text { Yes/No } \\ \text { E } & \text { Yes/No } \\ D & \text { Yes/No } \\ \text { C } & \text { Yes/No } \\ \text { B } & \text { Yes/No } \\ \text { A } & \text { Yes/No }\end{array}$

Yes/No

Yes/No

Yes/No

Yes/No

Yes/No

Yes/No

Yes/No

Yes/No

Yes/No

Yes

Yes/No

Yes/No

Yes/No

7.2.3 Test Engineer sign that steps 7.2.1 through 7.2.2 are complete.

Test Engineer Date

\subsection{THERMOCOUPLE TEST}

Using a multimeter or other calibrator and a heat gun, check operation of thermocouples that run from each detector to termination block in weathertight enclosure at top of probe. The end of each thermocouple should be heated and proper thermocouple response shall be verified with the multimeter or calibrator.

NOTE: Acceptance/rejection decision shall be based on results of manufacturers final calibration prior to shipping in conjunction with successful recording of thermocouple response to heat gun or other source of applied heat. 
RPP-7133, Rev. 0

7.3.1 Record model, serial number, and calibration expiration date of multimeter below.

Instrument:

SN:

Calibration Expiration Date:

7.3.2 Check thermocouple response to applied heat source.

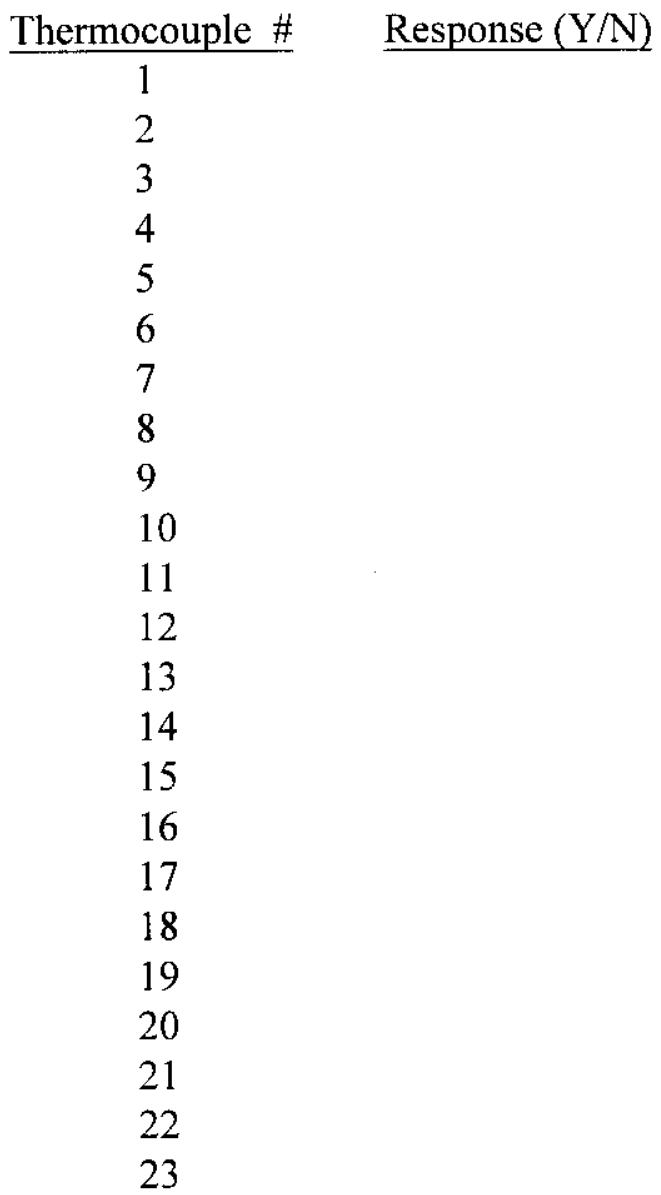

7.3.3 Test Engineer sign that steps 7.3.1 through 7.3.2 are complete.

Test Engineer

Date 


\subsection{RECORDS}

\section{TEST WITNESSES}

Test Personnel Attendance Sign In:

\section{Date}

Other Personnel Present:

Print Name

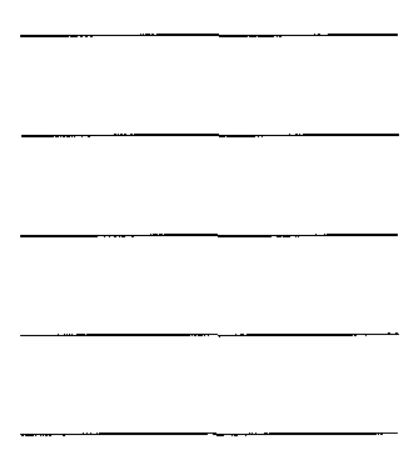

\subsection{EXCEPTIONS}

Signature

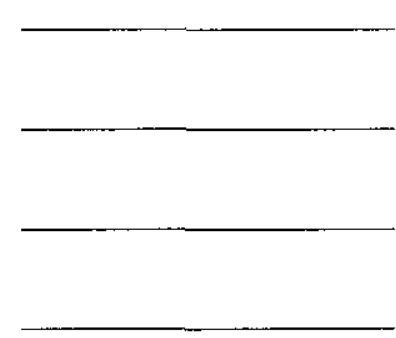

ITEM

\begin{tabular}{|l|l|l|l|}
\hline ITEM & STEP & DESCRIPTION & DISPOSITION \\
\hline & & & \\
\hline & & & \\
\hline & & & \\
\hline
\end{tabular}

TEST APPROVED WITH/WITHOUT EXCEPTIONS:

Test Engineer

\section{Date}


RPP-7133, Rev. 0

\subsection{TEST EXECUTION RECORD}

\begin{tabular}{|l|l|l||}
\hline Section & Accept/Reject & Remarks \\
\hline 7.1 & & \\
\hline \hline 7.2 & & \\
\hline \hline 7.3 & & \\
\hline
\end{tabular}

Test Engineer

Date 